\title{
DIE ENGLISCHE
}

\section{GERICHTSVERFASSUNG}

Eine systematische Darstellung

\author{
Von
}

DR. HEINRICH B. GERLAND

a. o. Professor an der Universität Jena

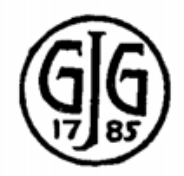

Leipzig

G. J. Göschen'sche Verlagshandlung

1910 
Alle Rechte von der Verlagshandlung vorbehalten.

Druck von Oscar Brandstetter in Leipzig. 
Erster Halbband. 


\title{
Sir Harry B. Poland, K. C., I. P., D. L.,
}

ehemals Recorder von Dover und Alderman des London County Council

$$
\text { und }
$$

\section{Dr. Ernst Schuster}

Barrister-at-law

gewidmet

\author{
vom Verfasser.
}

